China Perspectives

$2010 / 3 \mid 2010$

Taiwan: The Consolidation of a Democratic and Distinct Society

\title{
The Fiction of Living Beings
}

Man and Animal in the Work of Mo Yan

\section{Yinde Zhang}

\section{OpenEdition \\ Journals}

Édition électronique

URL : http://journals.openedition.org/chinaperspectives/5313

DOI : 10.4000/chinaperspectives.5313

ISSN : 1996-4617

Éditeur

Centre d'étude français sur la Chine contemporaine

Édition imprimée

Date de publication : 15 septembre 2010

ISSN : 2070-3449

\section{Référence électronique}

Yinde Zhang, "The Fiction of Living Beings », China Perspectives [En ligne], 2010/3 | 2010, mis en ligne le 01 septembre 2013, consulté le 28 octobre 2019. URL : http://journals.openedition.org/ chinaperspectives/5313; DOI : 10.4000/chinaperspectives.5313 


\title{
The Fiction of Living Beings
}

\author{
Man and Animal in the Work of Mo Yan ${ }^{(1)}$
}

$\mathrm{M}$ o Yan's extremely diverse and original œuvre over the last three decades has given rise to a number of major critical works. ${ }^{(2)}$ The fictional universe of this author is generally perceived to be illuminated by a broad thematic spectrum, ranging from childhood memory through to the power of violence and the explosion of sensual experience in such works as Honggaoliang jiazu (The Red Sorghum Clan), Tanxiang xing (Sandalwood Torture), and Fengru feitun (Big Breasts and Wide Hips), to mention the most famous examples. ${ }^{(3)}$ Some critics focus on cannibalism, which is a particularly striking phenomenon in Jiu guo (Wineland, or Liquorland) owing to its ingenious narrative presentation. ${ }^{(4)}$ Others opt for studies of the whole opus supported by monographs ${ }^{(5)}$ or comparative ${ }^{(6)}$ investigations. However, his work calls for fresh reflection taking into account its evolution and his scarcely explored intentionality. This author's literary world cannot be reduced to the myth of Gaomi, his reinvented birthplace, or to culture-based interpretations. Within it there is to be found a universal vision and a way of writing that confronts the major issues facing mankind today. ${ }^{(7)}$ In this respect his urgent concern with man's animal nature is expressed through obsessively recurrent motifs which, while being rooted within a specific history and geographical location, are nonetheless among the fundamental questions troubling the world as it enters the twenty-first century.

The universe of Mo Yan's imagination is based on a new kind of humanism and a representation of society in which mankind is closely linked to the animal world, and this proximity is even what makes it human. Whether in a critical or in a celebratory vein, his work expresses an animal ethics that blurs the boundaries between our human selves and the otherness of animals, pointing towards a sense of community shared by all beings. This fiction of living beings, ${ }^{(8)}$ which owes less to metaphysics than to phenomenology, places the emphasis on sensual experience co-ordinated with an imaginative reinvention of biopolitics. The three recent novels, Sishiyi pao (Forty-one Cannon Shots), Shengsi pilao (Life and Death are Wearing Me Out), and Wa (Frogs), ${ }^{(9)}$ broaden the animal motifs to be found throughout his previous publications, and provoke reflections on the possibilities
1. This article is based on a paper given at the international conference on "The Asian novel and its translations" organised by Noël Dutrait at the University of Provence, 1516 October 2009. I would like to express my thanks to him and to the two anonymous reviewers for China Perspectives.

2. See Yang Yang (ed.), Mo Yan yanjiu ziliao (Studies on the work of Mo Yan), Tianjin renmin chubanshe, 2005. This work is a collection of the most noteworthy critical articles, in addition to providing a bibliography, pp. 581-608. See also World Literature Today, 74 3 , Summer 2000, which is a special edition on the work of Mo Yan.

3. Chantal Andro, "La valorisation de l'enfance dans l'oeuvre de Mo Yan," in Chantal Andro, Annie Curien, and Cécile Sakai (eds.), Tours et détours. Ecritures autobiographiques dans les littératures chinoise et japonaise au XXe siècle, Publications universitaires Denis Diderot, 1998, pp. 191-230; Yinde Zhang, "Le 'Réalisme cruel': à propos du Supplice de santal de Mo Yan" in Antonio Domínguez Leiva and Muriel Détrie (eds.), Le Supplice oriental dans la littérature et les arts, Dijon, Les éditions du Murmure, 2005, pp. 287-304.; David Der-wei Wang, "The Literary World of Mo Yan," World Literature Today, op. cit. pp. 487-94; Jianguo Chen, "The Logic of the Phantasm: Haunting and Spectrality in Contemporary Chinese Imagination," Modern Chinese Literature and Culture, no. 14, 1, Spring 2002, pp. 231-265 (see especially pp. 242-248, which deal with Mo Yan's Zhanyou chongfeng (The rediscoveries of two comrades in arms)).

4. Noël Dutrait, "L'Ecriture moderniste de Mo Yan dans Le Pays de l'alcool" in Annie Curien (ed.), Ecrire au présent. Débats littéraires franco-chinois, Editions de la Maison des sciences de l'homme, 2004, pp. 231-240; Howard Goldblatt, "Forbidden Food: The Saturnicon of Mo Yan," World Literature Today, op. cit. pp. 477-286; Kenny K. K. Ng, "Metafiction, Cannibalism, and Allegory: Wineland by Mo Yan," Journal of Modern Literature in Chinese, no. 1, 2, January 1998, pp. 121-48; Gang Yue, The Mouth that Begs: Hunger, Cannibalism, and the Politics of Eating in Modern China, Durham, Duke University Press, 1999, especially the chapter entitled "From Cannibalism to Carnivorism: Mo Yan's Liquorland," pp. 262-288.

5. Michael Duke, "Past, Present, and Future in Mo Yan's Fiction of the 1980s," in Ellen Widmer and David Der-wei Wang (eds.) From May Fourth to June Fourth: Fiction and Film in Twentieth-Century China, Cambridge, Harvard UP, 1993, pp. 295-326; Yinde Zhang, "Le Grotesque chez Mo Yan," Le Monde romanesque chinois au XXe siècle. Modernités et Identités, Honoré Chamtion, 2003, pp. 417-437.

6. Thomas M. Inge, "Mo Yan and William Faulkner: Influence and Confluence," The Faulkner Journal, no. 6, 1, 1990, pp. 15-24; Zhu Binzhong, Kuayue shikong de duihua Fukena yu Mo Yan bijiao yanjiu (A dialogue transcending the boundaries of space and time: Comparative studies of Faulkner and Mo Yan), Wuhan Daxue chubanshe, 2006.

7. There is little doubt that both the importance of the imagination and the aspiration to universality are what the author means by his stated intention to "get beyond one's native place." See Mo Yan, "Chaoyue guxiang" (Getting beyond one's native place), in Xiaoshuo de qiwei (The smell of the novel), Beijing, Dangdai shijie chubanshe, 2004, pp. 360-378.

8. "We began by cutting man off from nature and setting him up as a sovereign ruler; we believed that this would efface his most unchallengeable characteristic, namely that he is first and foremost a living being. And, by remaining blind to this shared quality, we have given free rein to every abuse ... by seizing the exclusive right to radically separate men from animals, and granting to the former everything that was taken from the latter, we [Western man] entered into an accursed cycle, and as this separating boundary was constantly pushed back, it served to separate some men from other men, laying the basis for a claim, in favour of ever more restrictive minorities, to the exclusive privileges of a humanism which was corrupted at its birth for having borrowed its very principle and notion from self regard," Claude Lévi-Strauss, "Jean-Jacques Rousseau, fondateur des sciences de l'homme," in Anthropologie structurale II, Plon, 1973, p. 53.

9. Shengsi pilao was published in English as Life and Death are Wearing Me Out, trans. H. Goldblatt, New York, Arcade, 2008. Two of these works are also available in French: Mo Yan, Quarante et un coups de canon, translated by Noël and Liliane Dutrait, Editions du Seuil, 2008; La Dure loi du karma, translated by Chantal Chen-Andro, Editions du Seuil, 2009. 
Mo Yan at the Frankfurt

Book Fair in October 2009.

(C) Basso Cannarsa / Opale of "living together" in a world that presupposes shared participation without human domination and discrimination between the species. The denunciation of human cruelty towards animals, the compassionate reciprocity favoured by metempsychosis, and the concretisation of anthropo-zoomorphism through images: such are some of the ways in which a biocentric pattern is given novelistic shape and sharply distinguished from anthropocentrism. ${ }^{(10)}$

\section{The denunciation of cruelty}

Mo Yan's work confronts us again with the question of man's absolute right over animals and the gratuitous nature of cruelty. The writer attributes this to our dogmatic adherence to modernisation, which exalts productivity and fetishises prosperity.

The slaughterhouse in Sishiyi pao is a condensation of the perverted versions of modernity that provide naked violence with a patina of legitimacy. In effect every horror has its source in this meat-processing factory, which glorifies the modernising projects of the local authorities and, more broadly, of the nation as a whole. The creation of such an enterprise in a rural area enables an increase of productivity, in comparison with the artisan butchery that used to be the village's principal but scarcely viable activity. The industrialisation that drags the countryside out of poverty proves capable of satisfying the authorities. Moreover, the food industry that replaces family butchery seems to eliminate cruelty, if cruelty means an intentional act carried out by the one who inflicts it in direct contact with the one who undergoes it. ${ }^{(11)}$ But Mo Yan takes a stand against the impersonal automatism of machinery, in order to unmask the massive cruelty concealed by the de-individualising nature of serial production.

As we have come to expect, the author proceeds through irony to lay bare the alliance between financial interest and the official ideology that compounds its atrocities with brazen effrontery. In fact, the factory was created not only to enrich the peasants but also ostensibly to put an end to the fraudulent practice of selling meat pumped full of water. Instead of highlighting the slaughtering process itself, Mo Yan chooses to represent another process known as "rinsing," which is supposed to "tenderise the meat." So the illegal process, which was formerly restricted to the level of a family activity, now becomes an organised legal one, fully compliant with public health and safety regulations. This whole "rinsing" procedure inflicts the greatest suffering on the animals, from the transport by lorry, which makes them giddy until they are unloaded, to the cages in which they are imprisoned throughout, and the iron bars that force them to re-

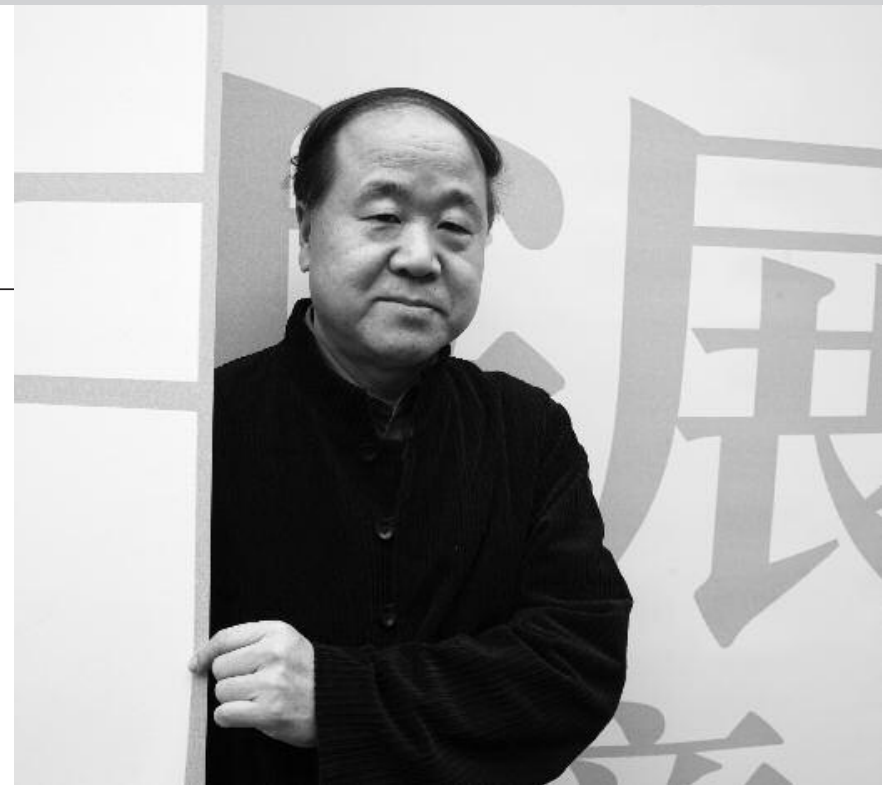

main standing. ${ }^{(12)}$ The relationship between the technical vocabulary and the actual means used, for example tying a rope to the horns and legs of the tortured livestock before dragging them on wooden rollers to the slaughterhouse, ${ }^{(13)}$ gives the lie to the smiling face of the industry, unless one is really to believe in the management's instructions to its workers to speak gently to the animals so they can "die with dignity" while providing high quality meat. Mo Yan not only uncovers the real physical suffering hidden by the publicity that promises both wonderful meat and a concern for public health, but also the damage caused by the language used to promote the values of modernity. By worshipping economic gain and collective utility, this language bestows a very dubious legitimacy on the massacre of animals.

Within this apparatus for the concealment of cruelty, the new dogma coincides with a set of cultural alibis. Modernisation becomes an absolute value by joining forces with the people's belief in prosperity, and thereby blinding them to the violence against animals. Significantly, the chapter on rinsing is located in proximity with two other episodes, one dealing with a meat-eating competition and the other with

10. Mo Yan's project effectively goes beyond traditional humanism, as he declares in an interview: "It seems to me that contemporary fictions dealing with animals tend to be stereotypical by projecting pseudo-humanist ideas onto them. It all seems rather hypocritical." "Mo Yan tan dongwu" (Mo Yan, discussions on animals), in Mo Yan duihua xinlu (New collection of interviews with Mo Yan), Beijing, Wenhua yishu chubanshe, 2010, p. 369).

11. Florence Burgat, "Défiguration et reconfiguration des animaux dans la présentation des viandes et dans l'imagerie publicitaire," "Animalités," Revue d'esthétique, no. 40, 2001, pp. 57-70.

12. The link between cruelty to animals and the fraudulence involved in meat production inevitably recalls the Chicago stockyards of the early twentieth century described by Upton Sinclair in The Jungle. This novel was translated into Chinese as "The Slaughterhouse" (Tuchang) and had a direct influence on Xiao Hong. Included in Shou (The Hands), it is echoed more significantly in Sheng si chang (Field of life and death) in the scene describing the slaughter of an old horse, and in more general terms this cruelty to animals functions as a metaphor for the dehumanising process undertaken in the northern territories under Japanese occupation in the early 1930s. See Xiao Hong, "Shou" (Hands), http://www.eywedu.com/Xiaohong/dpxsh/001.htm, and "Sheng si chang" (The field of life and death), http://www.eywedu.com?Xiaohong/shsch/004.htm (10 March 2010). Upton Sinclair's novel was first translated by Yi Kanren (Guo Moruo) as Tuchang, Shanghai, Nanqiang shuju, 1929.

13. Mo Yan, Sishiyi pao, Shenyang, Chunfeng wenyi, 2003, p. 292 
the Festival of Meat. In the first case, the company reaches its peak of production thanks to the competition, in which its productivity is measured by the stomach capacity of its leaders. The chief of the rinsing works would have been unable to take full advantage of this marketing stunt if he had not put on an unbeatable performance, which makes him a champion worthy of the title Meat Child. The quantity of meat devoured on this occasion, like the gastronomic sophistication displayed elsewhere, only avoids being equated with sheer greed because the villagers' voraciousness is dissolved into this highly suspect playfulness. By imagining such a game, the author is able to emphasise the ravages inflicted on the human spirit by a system whose only value is the display of power, in terms of both production and consumption, based on the consumption of animals.

The shared ideal of power, even of megalomania, is at the basis of the Festival of Meat, which is itself a perverted version of the old rituals of orgiastic sacrifice. The flags and the multicoloured chariots set up violent confrontations that evoke the world of baroque romance, while every variety of roasting meat emits its own aroma. Meanwhile, above the crowd abandoned to gluttony and drunkenness, fireworks trace out a gigantic character for the word "meat." This celebration of abundance turns to debauchery amidst total indifference to the scapegoats sacrificed on the altars of this triumphant materialism. As the cult of enrichment becomes the new creed and the cement of national cohesion, this dictatorship of consumerism exercises its power through a ritualised joy without sacred meaning. The perversion of the sacred can be read through a whole network of transgressive signs. The sacrilege consists less in the rejection of the Buddhist principle forbidding all animal sacrifice than in man's assumption of divine powers, as he imposes himself as master of the world and of all the creatures in it. The Feast takes place within a ceremony dedicated to the foundation of the Temple of the Meat God. This previously unknown divinity ensconced in Mo Yan's pantheon is born out of the deification of the Meat Child, who is celebrated in a spectacle and a book: The History of the Immortalisation of the Meat Child. ${ }^{(14)}$ His continued existence beyond death gives the child an ambiguous status: he is both the sacrificial agent, sated with his victims, and the god who enjoys a gratuitous transcendent power over them. The sacred is thus doubly corrupted, on the one hand by this sublimation of the carni$\mathrm{val}$, and on the other by the troubling identification of the human with the divine when the offering, the sacrificial act, and the godhead are all merged into one. But this parodied cult of the flesh also reveals the cult of money hidden behind the face of the god.

The building of the Temple of the Meat God goes together with the restoration of the statue of the god Wutong, establishing a dual tutelage of fortune and lust. ${ }^{(15)}$ This parallelism turns out to be insidiously suggestive rather than merely fortuitous, insofar as the figure of the centaur, assumed by the god Wutong, is represented in some legendary tales in the shape of a child who habitually finds pleasure with monks. ${ }^{(16)}$ The kinship between these two divinities becomes clear when the cannon-child assumes his role as narrator, throwing light on the links between the unrestrained consumption of meat, the ravages of lustful consummation, and the fetishism of prosperity. But the multiple identities of the child, who has degenerated into the flesh child, head of the rinsing works, and god of meat, are then made to give way to the textual rupture introduced by the cannon-child's role as narrator. The latter opens up a rift amidst the general impunity.

In fact, this novel is made up of the 41 stories told by the cannon-child to a monk, who is immured in an impassive silence in contrast with the narrator's unstoppable torrent of words. ${ }^{(17)}$ But the child's act of narration is in reality an expiation. The unending flow of the monologue is in every respect comparable to a confession. Mo Yan does not appear to question meat-eating per se, understanding fully its immeasurable complexity, even if elsewhere he praises the clan of the grass-eaters. But he gives prominence to the need to face up to reality by giving these clans his blessing, as Elisabeth de Fontenay puts it, ${ }^{(18)}$ especially as the reality in question takes on monstrous proportions. The narrator-protagonist finishes his tale by literally firing 41 cannon shots to pulverise Lao Lan and his factory, as if the destruction of the scene of the crime would allow the criminal madness to be expiated. But if there is an act of destruction, it is undertaken in order to remember better, and the cannon-child achieves such commemoration through the narration that completes his conversion. Although the other characters do not achieve this final break, they nonetheless live, like the

14. Mo Yan, Sishiyi pao, op. cit., p. 411.

15. Mo Yan, Sishiyi pao, op. cit., p. 191

16. "Master of an ancient pagoda" (Guta zhu), in Hong Mai, Notes from Yijian (Yijian zhi) [Yijian zhi gui juan shi guta zhu], Taipei, Mingwen shuju, 1995, vol. 3, pp. 1295-1296.

17. The importance of this narrative strategy in Mo Yan's work is supported by the author's own statement: "If one absolutely must define the plot of this novel, it consists precisely in the story of a child who narrates a story in an unstoppable flow." Mo Yan, "Afterword, Narration is all," in Mo Yan, Sishiyi pao, op. cit., p. 444.

18. Élisabeth de Fontenay, "Question animale, question politique," Relations, July-August 2001 (670), pp. 12-15. 
Cover of the French translation of Forty-one Cannon Shots: Mo Yan, Quarante et un coups de canon, trans. N. and L. Dutrait, Paris, Le Seuil, 2009. narrator, under the burden of casuistry. In their view, the domestic animals that have given their energy to humanity deserve a better fate than the slaughterhouse. If they cannot have a proper tombstone, they must at least have a burial place. For example, Huang Biao refuses to sell his plough ox, which is treated as though it were the reincarnation of his mother. On the initiative of the child's mother, Chen Yuzhen, a 10-metre high platform is raised so as to liberate the souls of these dead victims of injustice. ${ }^{(19)}$ This structure proves to be dedicated as much to the victimisers as to the victims, since it is the child's father, Luo Tong, who spends seven days there in obstinate solitary meditation. The irremediable occurs when, during his descent from it, he splits his wife in two in the same way that he used to finish off his animals. It is difficult to decide whether this fatal gesture is intended to punish her adultery or the criminal enterprise set up through the complicity between the legitimate and the illegitimate couples. Whatever the case may be, the deaths of Chen Yuzhen and Lao Lan, the imprisonment of Luo Tong, and Luo Xiaotong's renunciation lead to this dramatic outcome, while also expressing the overriding need for reparation.

\section{Compassionate awareness}

The demonstration of cruelty and sadism is accompanied by a sense of compassion. The accusations on the charge sheet are therefore counterbalanced by a more positive mode, based on pity towards all living beings, without any distinction between man and beast. The author invokes a Buddhist view of things to imagine a universe in which human and non-human animals would cohabit, communicate, and permutate among themselves. More than his other works, Life and Death are Wearing Me Out expresses this empathy between and across the species, mediated by a story of transmigration that is meaningful as well as being a fantasy.

With the coming of the People's Republic, Ximen Nao, a former landowner executed during the agricultural reforms, undergoes successive reincarnations as a donkey, an ox, a pig, a dog, and a monkey. Thus he becomes both witness and participant in half a century of the country's history. His metamorphoses into several domestic animals keep him in contact with his family and his village, without any event escaping his notice. The animal within his lower body lives a social life rich in passing events, just like the human beings around him. His interactions with the latter enable the author to expound a bio-centred ethics, both from within the character's viewpoint and from outside.

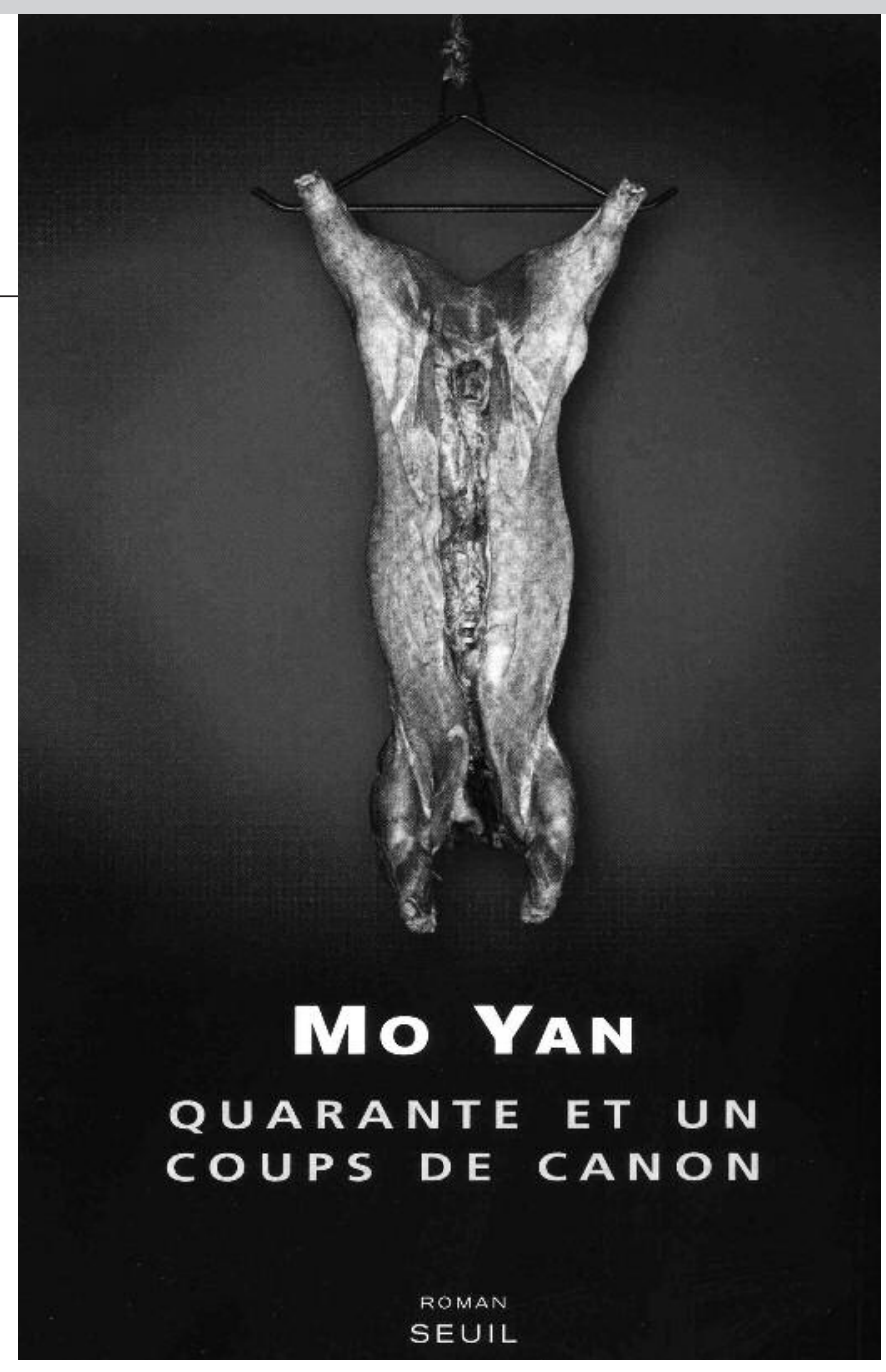

This ethics is made manifest in the first instance by pity for the community of suffering beings. In most instances, the feeling of the unbearable arises out of face-to-face situations. For example, the injured donkey causes his master Lao Lan to sob as he struggles to free his trapped hoof. Moreover the care and affection shown by the master have dissuaded the donkey from his suicidal intention, according to the rescued creature himself. ${ }^{(20)} \mathrm{Or}$ again, Huang Huzhu, who is in love with Ximen Jinlong, casts aside all propriety at the sight of her beloved covered in blood, and hurls herself upon him "like a tigress protecting her cub." ${ }^{(2)}$ The sight of the unbearable arouses an immediate and disinterested reaction that transports the onlooker towards the other by creating an immediate identification. The impossibility of indifference has its roots in Buddhist compassion, but it also recalls the

19. Mo Yan, Sishiyi pao, op. cit., p. 256. The "souls" here are the shades of the dead victim of an injustice, yuanhun.

20. Mo Yan, Shengsi pilao (Life and death are wearing me out), Beijing, Zuojia chubanshe 2006, p. 81-82. This motif recurs in several different texts. See for example, "Horse's hoof" (1985), which describes the fracture of a horse's rear hoof, a traumatic scene that causes the resurgence of an analogous memory going back to the previous decade. Mo Yan, "Mati" (Horse's hoof), in Xiaoshuo de qiwei (The scent of the novel), op. cit. pp. 267273

21. Mo Yan, Shengsi pilao, op. cit., p. 266

22. "The only hope, for each one of us, not to be treated as an animal by his fellows, is that all these fellows, starting with himself, should feel themselves to be suffering beings and should inwardly cultivate this aptitude for pity" Claude Lévi-Strauss, "Jean-Jacques Rousseau fondateur des sciences de l'homme," in op. cit. p. 54. 
cult of sensibility initiated by Rousseau ${ }^{(22)}$ and the daily experience of piety in the work of Schopenhauer. ${ }^{(23)}$ This capacity to feel the suffering of others also refers to the anecdote of the ox reported by Mencius: A king who was unable to bear the sight of an ox being dragged off to sacrifice ordered that it should be replaced by a sheep. ${ }^{(24)}$ This was not a matter of substituting a smaller item for a bigger one but the experience of a face-to-face meeting that, according to $F$. Jullien, is sufficient to set up a sense of fellowship with another existence, human or animal, because "it is existence itself that, through me, rises up in favour of another." It is a movement quite separate from any egotistical aim, ${ }^{(25)}$ and this primal emotion, arising from this shared existence, expresses no other link save that with life itself. Such a shared participation in life is naturally complemented by the rejection of indifference to death. Although burial for animals is only the object of a hollow promise in Sishiyi pao (Forty-one Cannons), it becomes a tangible reality in Shengsi pilao (Life and Death are Wearing Me Out), since the many mortal remains within which the reincarnated protagonist completes his life have actually been buried. The dignity of animals finds its supreme expression in this eternal rest, because mourning for these animals prevents them from dying alone; their life is recognised, just like a human life, which means they deserve the same funeral lament. ${ }^{(26)}$

Yet the compassion conveyed in Mo Yan's work is not really reducible to the one-sided attribution of feelings to "humanity." This would risk becoming a repetition of the speciescentred fable, which assigns to man alone the power to experience pity for the fate of the threatened, violated, and massacred animals. Accordingly, Mo Yan is not content to just express a sensitivity or emotional immediacy, which is sometimes merely impotent and is incapable of arriving at a rational basis for rights. Life and Death are Wearing Me Out leads to a more reflective compassion in the sense that it is more contextualised and more functional. This novel valorises certain kinds of potentiality or functional aptitudes ${ }^{277}$ that show individuals in their real capabilities tested in specific contexts. Such capabilities are shown to exist among human and non-human animals alike, and this opens the way to recognising their rights. In this way, the novel expounds a more political compassion that, being supported by a justified use of emotion, operates rather through a sense of solidarity and reciprocity between men and animals.

This reciprocal compassion is to be seen above all in the common participation in suffering and pleasure, transcending the boundaries of anthropocentrism. Thus, throughout these chapters it is not uncommon for animals to weep or smile on behalf of the human beings around them. The dog enters the tomb prepared for him by his master, only after accompanying the latter to his own grave. For his part, the ox sticks by his master, Lao Lan, when he refuses to join the People's Commune: he abandons the collectivised land in order to return to his master's independent pasture, braving the deadly blows rained down on him. ${ }^{(28)}$ By means of this osmosis between two suffering creatures, the "tears of blood" mingle with the stifled cry rising up against injustice and against a totalitarian regime incapable of tolerating the existence of this "only independent peasant in the whole of China."

Although compassionate awareness grows stronger in a relationship of interdependence between humans and animals, sensitivity alone is not enough to define behaviour. The faculties of perception, imagination, and even reason, allow the animals to build a world in which they acquire the legitimate right to forge relations with the human species, in the same way that some humans are able to care for animals. On their own initiative the animals seek to develop a relationship of co-operation and mutual aid with mankind, by conducting organised struggles against every form of injustice and seizing opportunities for expansion. Thus the canine protagonist challenges the status of servant companion assigned to him, because in his eyes his master, who is so dependent on him, is equally deserving of that title. The dog's self-promotion to equal subject is also confirmed by his involvement in the sentimental entanglements of his close human kin, thanks to his

23. Moreover Schopenhauer refers to the Chinese -- based on a translation of Mencius (Mengzi) by Stanislas Julien -- and to the Hindus when he asserts: "Lacking the philosophy of the Schoolmen, whose authority I can invoke here, I would add the following: that the Chinese proclaim five cardinal virtues (Tschang), among which they give pride of place to pity (Sin). The four others are Justice, Courtesy, Wisdom, and Sincerity. Similarly, among the Hindus, on the memorial tablets raised to remember the dead, the virtues for which they are praised include, in the first line, pity towards men and animals," quoted from the French translation: Le Fondement de la morale, trans. by A Burdeau, Librairie Germer Baillière et Cie, 1879, p. 164.

24. Mencius, French translation by S. Couvreur, in Les Quatre Livres, Taipei, Guangqi chubanshe, 1972, p. 314.

25. F. Jullien, Fonder la morale, Grasset 1995, p. 14.

26. At least, this is the same interpretation that Karl Weil makes in the case of J. M. Coetzee's novel Disgrace. See Karl Weiss, "Liberté éhontée," Critique, AugustSeptember 2009, p. 677. He identifies a "shameful empathy" in Professor Lurie's response to the euthanasia of a lame dog, since he sees the kinship between himself and his dog as one based in humiliation and shame, over growing old and approaching death. It is not a matter of maintaining the ideal of "moral uprightness" in the words of Francione, who believes in ending the lives of domestic animals in order to preserve our good conscience sullied by the master-slave relationship. The essential point is that animals should not die alone, that they should be able to die surrounded by love because, as the end of Coetzee's novel shows, the protagonist does not desire the dog's disappearance but wishes to mourn their shared shame.

27. Olivier Renaut, "Un bon usage de la compassion: Martha Nussbaum, Frontiers of Justice," Critique, August-September, 2009, pp. 771-779.

28. Mo Yan, Shengsi pilao, op. cit. p. 172. 
highly developed sense of smell, which makes him an incomparable detective. The pig, who has "clear ideas" in his natural state, but whose brain "gets fuddled" as a human being, attacks Hong Taiyue because the animal cannot put up with the sadism inflicted by the hardened old Communist on Lady Bai, a former landowner and his own principal wife in a previous life. ${ }^{(29)}$ In addition, the pig who shows himself able to act out of noble feelings perishes in his attempt to save some children who are drowned in freezing water. ${ }^{(30)}$ The dog's cunning manoeuvres, the pig's act of bravery, and the self-sacrificing faithfulness of the ox arise from decisions that combine spontaneity with conscious will, allowing them to fully become themselves through the relations with others that they manage to establish.

The interaction between man and animal overcomes not only anthropocentrism, but also a mode of representation focused on suffering that is too liable to charitable humanism and an exclusively death-centred view of biopolitics. The mutual entanglement of men and animals tends to take the form of a hybrid community, characteristic of societies where men live with animals and as animals. In this respect, nothing could be more expressive of the continuum of life than this cross-bred narrative style. The narration is conducted through alternation and combination. Two voices, one human and the other animal, take turns from section to section, and from chapter to chapter, as in the penultimate section (chapters 50 and 53), for example. Mo Yan, the protagonist who bears the author's name, takes charge of the final section, which serves as a prologue after plunging intermittently into the story from time to time. This switching of the narrative voices places the tale under a constant process of confrontation and confirmation. A truly dialogical exchange is set up when the narration is carried out in the second person singular, allowing man and animal to establish relations of empathy through these acts of enunciation. So the hybridity is built into the novel's structure.

The novel opens and closes on the same date, 1 January 1950, enclosing the story and its written narrative within a perfect circle. This hermetically sealed circularity seems to condemn the protagonist to definitive failure by sublimating the karmic cycle without even giving him the chance to recover his human form. Yet, properly speaking, his metamorphosis is not irreversible; his human nature will be more or less recovered later in a "genetically modified" form. At the end of this repetitive series of transmigrations, Ximen $\mathrm{Nao}$ remains on the threshold of a reconquered humanity, in the body of a primate, while at the same time there is another birth, of a frail being with a "strangely enlarged head" ${ }^{(31)}$ and the memory of an elephant with the gift of language. This "baby of the century," a haemophiliac whose life depends on ashes obtained from his grandmother's abundant newlygrown hair, has more or less the characteristics of a reconstituted human being. This resurrection coincides with the advent of the new millennium, and announces the emergence of an anthropo-zoomorphism, which in reality arises from the shared roots in life. This "humanimal" future has in fact its own historical trajectory. Ximen Nao's metempsychosis recalls not only the descent into hell, but even more clearly the ancestral relations between the human and animal realms. His repeated reincarnation makes him the generating patriarch of a prolific kinship open to polymorphous animal connections. The spreading family descent, whose multiple origins, moreover, are traceable back to polygamy, adultery, and adoption, exists within a micro-society rooted in an anthropo-zoomorphic archetype. The baby of the century turns out "despite everything" to be the inheritor of the patronymic "Lan," i.e. "Blue," out of respect for his ancestors whose faces bore this bestial, or demonic, stigma. This cross-breed pedigree is authenticated by the fact that he was born from an animal-loving mother, as the outcome of transgression and incestuous love. Here the break from the norms of the kinship structure refers to the myth of $\mathrm{Fu} X \mathrm{X}$ and Nüwa, a couple who were brother and sister with human heads and intertwining snakes' tails. The return to the origin (or plural origins) forcefully championed by the author receives its confirmation in this final chapter, which allows the emergence of primordial desire.

\section{The "humanimal" body}

The theme of animality lends itself to both teleological and mythical treatment. The sequential introduction of the different animals, far from being haphazard, embraces the development of Chinese society, with the donkey and the ox as beasts of burden immersed in the scene of collectivisation, the pig as the sign that announces and then confirms abundance, and the dog as the domestic companion in China as it undergoes accelerated urbanisation. But there is a timelessness within this animal presence in human society, as is made instantly clear by the above allusion to the mythical couple, and even more clearly by the totemic role of the mare in Shi cao jiazu (The Clan of the Straw-eaters), when

29. Mo Yan, Shengsi pilao, op. cit. p. 349.

30. Mo Yan, Shengsi pilao, op. cit. p. 366-367.

31. Mo Yan, Shengsi pilao, op. cit. p. 540. 
the boy calls out "Ma" in a disquieting confusion of the words for "Mother" and "Mare." (32) This topos ends up affecting the novel's whole universe, shaping the text itself as a hybrid entity. In effect, Mo Yan's work becomes an immense body, built through a process of hybridisation that acts upon the characters, the rhetoric, and the textual structures.

In all of Mo Yan's novels one finds the cohabitation of men and animals, and even communication between them. This co-presence in the world is given clear form in the characters who have been metamorphosed or hybridised. The reincarnation of Ximen Nao, quite unlike the irreversible process of degradation, gives him the dual faculties of man and animal. Metempsychosis is presented less as a case of metemsomatosis (the incarnation of a human soul in an animal body), than as proof of the impossibility of a split between body and mind. This is attested by the different chapter headings: "the donkey's torments," "the ox has recourse to obstinacy," "the pig gives himself up to joy," "the dog's temperament," without mentioning the sub-headings that summarise the behaviour and affects of the animals. The animal body here is no longer the object of behaviourist observation of its mechanical gestures, nor is it just a vehicle for human feelings. It is a dynamic body with its own moods and thoughts, which ultimately come up against the "harsh law of karma" (title of the French translation of Shengsi pilao). That is why the pig says he is lucid in his pig's body, but has a befuddled mind in his human form. ${ }^{(33)}$ The grotesque animal body provides a metaphor for the living body of any kind, giving an expressive form to the conscious life within. There is little doubt that this perspective allows us to decipher the hybrid characters, like the child prodigy covered in scales in Wineland, or the girlbird in Big Breasts and Wide Hips. Their prodigious physical faculties are proportionate to their sensual experience, amplified to the point of forming their subjective consciousness.

The construction of these characters is only made perceptible through what might be called verbal "animations," which enable the image to become embodied. The author visualises conceptual resemblances through a systematic play with parallelisms and comparisons. In Big Breasts and Wide Hips, when Shangguan Lushi and the female donkey both give birth at the same time, this overwhelms the mother-in-law, Shangguan Lüshi, for whom these shared "deliveries" are two equivalent pieces of "good news." (34) Again, the mother, who is literally roped in like a mule to work the collective mill, risks her life to steal some beans from the People's Commune to save her children from star- vation. Through this redeeming gesture she unconsciously repeats the selfless behaviour of birds, which ingurgitate to feed their young by regurgitation. In both cases the analogy reveals the strength and generosity of the nurturing mother. The praise of the body is sometimes conveyed through the critique of the way it is instrumentalised. In this rhetorical pattern, the parallelism sometimes even turns to a chiasmus. For example, in a burlesque scene, the pig is covered in revolutionary signs and slogans that turn him into a "revolutionary billboard." ${ }^{(35)}$ The chiasmic crossover occurs when the children in their turn, now dressed as revolutionary pigs, climb onto the stage to perform their act of "fidelity" to the great leader. ${ }^{\left({ }^{(3)}\right)}$ These scenes point ineluctably back to the procession of camels "all covered in red silk and decorated with a flower as they come to receive their reward" during the Festival of Meat. ${ }^{(37)}$ The mocking "sublimation" subverts the revolutionary and consumerist gods alike, recalling two separate historical periods that share a common corruption of the body.

But these combinatory figurations of the body are directly reliant on verbal tropes. Here the most striking stylistic feature is the use of comparison. ${ }^{(38)}$ Although there is regular recourse to natural elements, men and animals actually interact in a more systematic way. There are numerous character portrayals and descriptions of gestures or postures in which playful comparisons blur the boundaries between man and animal, as can be seen in the following two examples from Sishiyi pao: "He [the monk] was perfectly calm, like a dozing horse"; ${ }^{(39)}$ "If they [the animals] had not uttered groans like old women with toothache, you would hardly have thought that they were alive." ${ }^{(40)}$ The first example establishes a parallel between the meditating monk and a sleepy horse, the two species being semantically

32. Mo Yan, Shi cao jiazu, Beijing, Dangdai shijie chubanshe, 2004, p. 113

33. Mo Yan, Shengsi pilao, op. cit. p. 349.

34. Mo Yan, Fengru feitun (Big breasts and wide hips), in Mo Yan wenji (Works), Beijing, Dangdai shijie chubanshe, 2006, p. 9.

35. Mo Yan, Shengsi pilao, op. cit., 2006, p. 232. The original word for "billboard" is xuanchuan lan ("publicity column")

36. Mo Yan, Shengsi pilao, op. cit. p. 240-241.

37. Mo Yan, Sishiyi pao, op. cit., p. 131.

38. For the issues raised in the translation of Mo Yan's style, see Liliane and Noël Dutrait, "Atelier de chinois," Dix-huitièmes assises de la traduction littéraire (Arles 2001), Actes Sud, 2002, pp. 76-78.

39. Mo Yan, Sishi yi pao, op. cit. p. 1. The original reads: "Da heshang duanzuo zai pobaibukan de Wutongshen suxiang qian yige fulan de putuan shang, shenqing anxiang, fangfo yipi meng zhong de ma" (see glossary).

40. Mo Yan, Sishi yi pao, op. cit., p. 353, reads:"Ruguo bu shi tamen fachu de hengheng jiji de, xiang laotaitai hai yatong yiyang de shengyin, ni jihu xiangbudao tamen shi yixie huowu." The final expression huowu means literally "living beings." 
linked by their shared serenity. The second describes a dog market in which the dogs' suffering in their motionless bodies would have been unnoticeable if they had not uttered their human, or more precisely their elderly people's groans; this analogy draws its power from evoking the suffering common to both sets of defenceless creatures. The proliferation of such comparisons actually goes beyond their shared suffering to refer to that of the world itself, since neither man nor animal is restricted to one side or the other in the comparison. On the contrary, through their perception and their feelings of interchangeability, they compare, contemplate, and exchange their positions. Comparison involves metonymic devices - the horse is close to humans, and the statue of the centaur in the temple is even closer and this points to an environment shared by men and animals that, far from existing in an asocial world, actively participates in society.

The "humanimal" entanglement evoked in the language games reaches its climactic expression in Mo Yan's latest novel Frogs, ${ }^{(4)}$ as is shown by the homophonic links set up by the sound of the character for "frog" (wa 1) in the title, which then refers to the character for "baby" (wa 2), and finally settles on wa (wa 3), which comprises one side of Nüwa, the goddess and creator of human beings. These homonymic associations operate as links in the diegesis, associating the issue of the murderous birth control policy with the denunciation of the organised trafficking in surrogate motherhood under the cover of a commercialised trade in bullfrogs. But they also have a symbolic range beyond these rhetorical effects. The disquieting imaginary world, in which the midwife charged with a holy mission doubles as an abortionist, allows Mo Yan to lift the taboo on bioethical considerations by invoking the power of myth and allegory. This occurs when the activities of Nüwa are submitted to a "judgement of Solomon" (42) that problematises the definition of human identity in terms of the family tree and kinship descent.

Far from raising man to supreme mastery, the new fictional language games, deployed as they are through the signifying chain of the frogs, reaffirm the writer's obsession with interspecies being endowed, moreover, with sacred meaning. In this respect Frog Babies is closely connected to The Frog God by $\mathrm{Pu}$ Songling, ${ }^{(43)}$ an author practically worshipped by Mo Yan: there these tailless amphibians are benevolent deities who engender and protect mankind on condition of a reciprocal relationship in which men fulfil their duty to show them veneration, respect, and protection in return.
This last example suggests that in the final analysis, the inscription of the hybrid body transforms the texts themselves into a living organism. From its imagistic language to its proliferating narrative forms, the same vital weave of language runs through a textual structure borrowed from phenomenology. Whereas The Sandalwood Torture develops around a rather playful animal morphology, "Phoenix head," "Pig's belly," and "Leopard's tail," by contrast, the animal embodiment arises from more serious motives in the narrative voice that, inspired by the melodious sound of the cat, breathes notes of suffering into a text as disjointed as the murdered body of the protagonist. This narrative voice continues into Sishiyi pao as that of the cannon-child, whose voluble flow conveys his corporal failings along with his expiatory tale. The scriptural quality of the body perpetuated by this imperishable voice ends up by thematising the work around the notion of a biological writing. Accordingly, compassion itself is conceived as naturally inscribed into a respect for all related beings, about whom one no longer seeks to know whether they are human or non-human, since all that matters is the solidarity across the species made possible through the playful displacement of pronouns. The constant slippage of "I" into "we," quite unlike Rimbaud's

41. See Mo Yan, Wa (Frogs), Shanghai, Wenyi chubanshe, 2009. This tale is most probably the product of a long gestation, because in an essay written several years ago, Mo Yan promised to write a novel about frogs: "Hongshui, niuwa" (Floods and bullfrogs), in Mo Yan sanwen xinbian (A new collection of essays by Mo Yan), Beijing, Wenhua yishu chubanshe, 2010, p. 160. In fact, certain episodes in the novel recall the scenes described in the essay, such as the frogs invading the village after the heavy downpours in the 1960s.

42. The last part of the novel is written as a theatrical parody in which Chen Mei, the clandestine and maddened surrogate mother, contests the baby's maternity with Xiao Shizi (Little Lioness), the putative genetic mother. The intervention of the judge, Gao Mengjiu, recalls the biblical scene, or rather Huilan $j i$ (The Chalk Circle) by the Yuan dynasty playwright Li Xingdao, since Gao compares himself to the figure of the impartial Judge Bao. But Mo Yan's dramatised episode proposes a version aimed at the relationship between bio-ethics and the world of real living beings. This drama, and the novel itself, ends after the judgement in favour of the genetic mother, with the failed suicide of the Aunt, trapped by her guilty conscience over the multitude of abortions she has performed throughout her career as a midwife. From then on she remains obsessed by the croaking of frogs, which sounds like the cries of babies from beyond the grave. Mo Yan, Frogs, op. cit. pp. 281-340. We should remember that Li Xingdao's played inspired Brecht to write his Caucasian Chalk Circle. Li Xingdao's play was translated into French by Stanislas Julien. See Li Hsing-dao, Hoei Lan Ki ou l'histoire du cercle de craie, London, Oriental Translation Fund, 1832.

43. Shiniang, (the Tenth), a reincarnation of the frog divinities, marries Kun Sheng (bachelor Kun) at the same time as the house is invaded by bactrians. The house undergoes a series of misfortunes after the husband offends them by ill-treating his wife. Peace and prosperity return when the wife is once again respected and the rites are properly observed in the sanctuary dedicated to the frog deity. She then gives birth to two boys. See "Qingwa shen" (The Frog God), in Pu Songling, Liaozhai zhiyi (Chronicles of the strange), Beijing, Renmin wenxue chubanshe, 1989, pp. 1446-1450.

44. This constant play with the slippage of pronouns is particularly striking in the writer's use of zan, which in the published French translation Chantal Chen-Andro does not hesitate to translate as "nous" [we]. Mo Yan, La dure loi du karma, op. cit. pp. 555-556. See the original Mo Yan, Shengsi pilao, op. cit. pp. 384-387. 


\section{Article}

"I is another" means rather that "I is they," insofar as the "we" is the incarnation of an infinitely transposable instance, like a chain of contagious metamorphoses. ${ }^{(4)}$ In the absence of a utopia of universal coexistence, this "we," designed to rally others as much as to implicate them, at least raises the hope of rediscovering what another butcher's son,
Pierre Dac, a humorist and member of the French resistance, incisively summed up as the missing link between monkey and man.

\section{- Translated by Jonathan Hall}

\section{Glossary}

Da heshang duanzuo zai pobaibukan de Wutongshen suxiang qian yige fulan de putuan shang, shenqing anxiang, fangfo yipi meng zhong de ma 大和尚端坐在破敗不堪的五通神塑像前一個腐爛的蒲團上, 神情安詳, 彷彿一匹睡夢中的馬

huowu 活物

Nüwa 女媧

Ruguo bu shi tamen fachu de hengheng jiji de, xiang laotaitai hai yatong yiyang de shengyin, ni jihu xiangbudao tamen shi yixie huowu 如果不是它們發出的哼哼唧唧的、像老太太害牙痛一樣的聲音, 你幾乎想不到它們是一些活物

wa 1 蛙

wa 2 娃

wa 3 媧

xuanchuan lan 宣傳欄

Yijian zhi gui juan shi « guta zhu » 夷堅志癸卷十《古塔主》

yuanhun 冤魂

zan 咱 